6. Honcharenko S. U. Ukrainskyi pedahohichnyi slovnyk

S. U. Honcharenko. - K. : Lybid, 1997.

7. Slovar praktycheskoho psykholoha / sost. S. Yu. Holovyn. - Mynsk : Kharvest, 1997

8. Kodzhaspyrova H. M. Pedahohycheskyi slovar / H. M. Kodzhaspyrova, A. Yu. Kodzhaspyrov. - M. : Akademyia, 2000.

9. Korotkyi tlumachnyi slovnyk ukrainskoi movy / Uklad.: D. H. Hrynchyshyn et al / za red. D. H. Hrynchyshyna. - K. : Vyd. tsentr "Prosvita", 2010.

10. Omelchuk S. A. Navchannia morfolohii ukrainskoi movy na zasadakh doslidnytskoho pidkhodu: teoriia i praktyka : monohrafiia / S. A. Omelchuk. K. : Heneza, 2014.

11. Honcharenko S. U. Pedahohichni doslidzhennia: metodolohichni porady molodym naukovtsiam / S. U. Honcharenko. - Kyiv ; Vinnytsia : DOV "Vinnytsia", 2008.

12. Obshchye osnovы pedahohyky : ucheb. dlia vuzov / V. V. Anysymov, O. H. Hrokholskaia, N. D. Nykandrov. - M. : Prosveshchenye, 2006.
13. Kahakyna E. A. Obosnovanye kontseptsyy kompetentnostnoho podkhoda k obuchenyiu studentov vuza / E. A. Kahakyna // Myr nauky, kulturb, obrazovanyia. - 2011. - № 5 (30). - S. 208-211.

14. Sistemnyy podkhod i sistemnyy analiz / I. V. Blauberg, E. M. Mirskiy, V. N. Sadovskiy // Sistemnyye issledovaniya. - M. : Yezhegodnik, 1982. - S. $52-58$.

15. Sovremennыe obrazovatelnыe tekhnolohyy : uchebn. posob. / pod red. N. V. Bordovskoi. - 3-e yzd., ster. - M. : KNORUS, 2013.

16. Zymniaia Y. A. Pedahohycheskaia psykholohyia : uchebnyk dlia vuzov I Y. A. Zymniaia. - 2-e yzd., dop., yspr. y pererab. - M. : Yzdatelskaia korporatsyia "Lohos", 2000.

17. Selevko H. K. Эntsyklopedyia obrazovatelnыkh tekhnolohyi : v 2 t. / H. K. Selevko. - M. : NYY shkolnukh tekhnolohyi, 2006. - T. 1.

18. Obucheniye russkomu yazyku $v$ shkole : ucheb. posob. / pod red. Ye. A. Bystrovoy. - M. : Drofa, 2004.

19. Anthony E. Approach, method and technique / E. Anthony // English Language Teaching. - 1963. - Vol. 17(2). - P. 63-67. Надійшла до редколегії 03.02.20

T. Miier, Doctor (habil.) of Science in Pedagogy,

Borys Grinchenko Kyiv University, Kyiv, Ukraine

\title{
DIDACTIC ESSENCE OF THE CONCEPT OF "APPROACH": GENESIS, INTERPRETATION, FUNCTIONALITY, HIERARCHY, CLASSIFICATION
}

Content creation of such components of didactic tools as paradigm, approach, principle, method, means, form, etc. is a long process, accompanied by the mutual influences of one concept to another. These mutual influences led to the identification of concepts or the differentiation of their content. In the course of the research it was found out that mutual influences were also characteristic for forming the content of the concept of "approach". On the basis of the analysis of philosophical, pedagogical, psychological and vocabulary sources, it was found that the process of isolation of the scientific approach as opposed to the extra-curricular approaches and approaches of theism and deism was revealed on the content of the concept "approach". The process of forming the content of the concept "approach" included: identification of the concepts "method" and "approach"; interpreting the latter using the words "method", "means" or based on one of them. It is proved that the interpretation of the content of the concept "approach" with the use of the concept "method" or "means" impedes the understanding of its content and hierarchical arrangement among the components of didactic tools.

As a result of the research, the concepts "method" and "approach" are delineated, morphological, lexical, structural, functional and axiomatic factors that influence the hierarchy of the components of didactic instruments are defined. A hierarchical ordering of the components of the didactic instruments concerning the organizing the educational process of students is also carried out. The definition of the concept "approach" is formulated by distinguishing the general and the partial in its content. The general is constructed on the basis of the phrase "a way of setting a strategic direction", and partly based on the characteristics of a particular approach, in particular axiological, valeological, humanistic, gender, activity, diagnostic, research, differentiated, hermetic, eco-differentiative, information, individual, communicative, complex, cultural and historical, cultural, personally oriented, synergistic, environmental, technological, holistic, value and approaches "optimization of learning", "inter-activity integration", "humanitarian education", "dyadic basis". The approaches are classified according to the orientation of their use.

Keywords: approach, approach in education, approach in organizing learning, scientific approach, purpose, content, method, paradigm, principle, form of organizing a learning process, form of organizing an educational activity.

\section{УПРАВЛІНСЬКА ДІЯЛЬНІСТЬ І. П. ЛЬВОВА НА ПОСАДІ ЗАВІДУВАЧА КАФЕДРИ ПЕДАГОГІКИ ЧЕРНІГІВСЬКОГО ПЕДАГОГІЧНОГО ІНСТИТУТУ (1952-1958)}

Проаналізовано діяльність чернігівського педагога І. П. Львова, який завідував кафедрою педагогіки з 1952 до 1958 н. р. Опрацьовано звітні матеріали (плани роботи кафедри за 1952, 1953, 1955 н. р., доповідь на резолюцію І. А. Каїрова "О состоянии педагогической науки и мерах ликвидации ее отставания", звіт про проведення державних іспитів та ін.), вказані недоліки й зауваження щодо навчального процесу в освітніх державних установах, які актуальні для сучасного менеджменту в освіті.

Ключові слова: резолюція, педагог, завідувач кафедри, І. П. Львов.

Постановка проблеми. У сучасних умовах реформування освіти України одним із пріоритетних завдань $є$ вивчення й адаптація до сучасних умов багатого історичного досвіду у сфрері освітнього менеджменту. Сучасні науковці, активно досліджуючи педагогічну діяльність видатних українців, усе частіше звертають увагу на їхні досягнення в управлінській діяльності, оскільки багатьом педагогам вдавалося поєднувати викладацьку діяльність із адміністративною (М. Ф. Берлинський, М.Х.Бунге, В.ІІ. Вернадський,

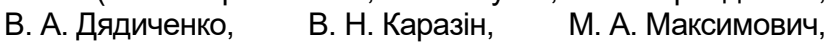
І. П. Львов та ін.). Дослідження й оприлюднення результатів успішної адміністративної роботи в освітніх закладах минулого дасть можливість виокремити та запровадити ідеї в управління сучасними закладами освіти.

Чернігівський педагог І. П. Львов зарекомендував себе не лише як досвідчений педагог, але і як досвідчений керівник кафедри педагогіки Чернігівського педагогічного інституту. За його керівництва на кафедрі педагогіки розпочав роботу педагогічний гурток, було створено куточок читача із психолого-педагогічною літературою.

За 1950-1951, 1952-1953 н. р. І. П. Львов як завідувач кафедри педагогіки та психології розробив план роботи кафедри, який було затверджено на засіданні. Нами проаналізовано план на другий семестр, у якому головним завданням була ефективна навчальна робота студентів, підвищення кваліфікації викладачів і здійснення громадських робіт під керівництвом викладачів. Зроблено акцент на затвердженні індивідуальних робочих планів членів кафедри, контролі за лекціями й заняттями 3 педагогіки з погляду наукового й методичного оформлення, контролі за роботою лаборанта, розгляді й затвердженні робочого плану педагогічної практики 
студентів, організації та загальному контролі за самостійною роботою студентів першого курсу 3 педагогіки. Щомісяця відбувалося обговорення інформації викладачів педагогіки про освітній процес студентів, звітів керівників практики, доповідей про методику проведення заліків із педагогіки, слухання звітів викладачів із педагогіки щодо результатів їхньої роботи за другий семестр, слухання робочих планів занять із педагогіки, психології студентів заочної форми навчання під час літньої сесії. І. П. Львова підтримала кафредра педагогіки щодо створення методики проведення консультацій для студентів заочної форми навчання, рецензування контрольних робіт, упровадження методик під час виїзних лекцій викладачами в заклади освіти м. Чернігова. Науковій роботі І. П. Львов приділив особливу увагу. Він зазначав про необхідність залучення студентів і викладачів до наукових, науково-методичних доповідей $[1,2]$.

Про адміністративну діяльність на посаді завідувача кафедри педагогіки свідчить інформаційна записка І. П. Львова про підготовку до нового навчального року та вказівки комісії з обстеження роботи кафедри. І.П. Львов перевірив стан обладнання із психології. Оскільки його термін використання завершився, необхідно було закупити нову апаратуру. Засоби навчання 3 педагогіки не вміщалися в тісному приміщенні, що унеможливлювало організацію та проведення самостійної роботи студентів. І. П. Львов вказав на необхідність поліпшення якості умов кабінету. Комісія виявила недоліки в лекціях із педагогіки, вказавши на: недостатнє використання дидактичного матеріалу для шкільних експериментів); відсутність планів лекцій; відсутність систематичного контролю якості лекцій.

І. П. Львов мав намір організувати секційні методичні об'єднання для викладачів логіки та психології. Щодо наукової роботи, то він працював над статтею "Методичні вказівки щодо викладання логіки в середній школі". І. П. Львов запланував написання статті "Першочергові задачі перебудови психології на головних початках фрізіологічного спадку акад. І. П. Павлова". І. П. Львов додав, що посилено відбувався контроль і перегляд письмових матеріалів студентів, систематично організовувався контроль за проведенням консультацій для студентів. Навчальними підручниками та програмами студенти забезпечені [3]. Отже, І. П. Львов виявив негативні моменти в роботі викладачів Чернігівського педагогічного інституту: а) викладаючи педагогіку, вони поверхово вивчали навчально-виховний процес у школі; б) існувала визначена особливість у викладанні педагогіки та психології, що віддзеркалювала загальну тематику й постановку програм із педагогіки і психології; в) програма із психології мала менше годин, ніж програма з педагогіки [6].

Варто зауважити, що І. П. Львов мав намір придбати окреме приміщення для проведення психологічних експериментів. Однак це не вдалося реалізувати через невідомі причини. Водночас І. П. Львов казав, що інститут допомагав школі, читаючи лекції методико-педагогічного характеру. На думку І. П. Львова, викладачі інституту мають читати популярні лекції батькам учнів і тим самим педагогізувати батьків; студенти інституту повинні були включитися в роботу класних керівників, виконувати різні види класної та позакласної роботи з учнями [3].

У 1951 р. на засіданні вченої ради фракультету І. П. Львов прозвітував про діяльність кафедри педагогіки Чернігівського учительського інституту: педагогічними кадрами кафедра педагогіки забезпечена; склад кафедри: завідувач кафедри, старший викладач педагогіки Н. Ф. Проценко, асистент кафедри педагогіки І. П. Куценко [2].
Робочі навчальні плани з дисциплін кафедри заслухали й обговорили з погляду ідеологічної та наукової витриманості, насиченості тематики, а також із боку колективу й ідейних якостей. Лекції викладали на достатньому рівні [2].

Методична робота кафедри, за інформацією І. П. Львова, проводилася вчасно. Кафедра здійснила підготовчу роботу, пояснивши студентам, як читати рекомендовану літературу, виписувати інформацію в конспекти. Лаборант кафедри педагогіки та психології забезпечувала студентів списками рекомендованої літератури, самою літературою й навчальними програмами. Кількість годин для консультацій викладачами кафедри була перевиконана. За 1951-1952 н. р. І. П. Львов у звіті, що вище вказаний, повідомив, що забезпечення студентів навчальною та навчально-виховною літературою було недостатнім, програми $з$ педагогіки, психології підходили більше для заочного відділу інституту. Новинки бібліографічних видань психології та педагогіки на кафедру приходили із запізненням, оскільки був відсутній контроль.

І. П. Львов акцентував увагу на проведенні педагогічної практики студентів у школі, зауваживши про наявність усіх необхідних матеріалів на кафедрі педагогіки та психології (необхідну літературу, кращі зразки документів із педагогічної практики студентів за попередні роки) [1].

Контролюючи якість лекцій і семінарських занять із педагогіки, лекцій із психології, І. П. Львов прозвітував про відвідування дирекцією інституту й окремими членами кафедри занять, які вони стенографували та рецензували [2].

І. П. Львов консультував викладачів психології шкіл м. Чернігова, відвідував їхні уроки, за завданням науково-дослідного інституту психології УРСР вивчив стан викладання психології у школах № 6 і № 7, застосування вчителями заходів заохочень і покарань [2].

У 1953 р. завідувач кафедри педагогіки І. П. Львов підготував звіт про роботу кафедри педагогіки Чернігівського педагогічного інституту за 1952-1953 н. р. У звіті вказано на необхідність забезпечити школярів усім потрібним для виховання й навчання, високу ідейність виховання молоді у патріотичному дусі [2].

На вченій раді Чернігівського педагогічного інституту заслухали навчальну й методичну роботу кафедри педагогіки, про що доповідав завідувач кафедри І. П. Львов. Робочі навчальні плани з усіх дисциплін кафедри обговорювалися своєчасно на чергових засіданнях [2]. Протягом навчального року, за статистикою І. П. Львова, кафедра провела заходи з реорганізації тематик робочих планів із психології та педагогіки [2]. Для розробки тем семінарських занять вказувалося мінімум літератури, студенти писали конспекти. Семінарські заняття проходили у вигляді питань викладачів і відповідей студентів. Активність студентів на заняттях була мала, незначна кількість студентів підтримувала дискусію [2]. На кафедрі педагогіки під керівництвом І. П. Львова студентам у вечірній час надавали допомогу у вигляді групових консультацій, практикувалися позапланові індивідуальні консультації [2].

У 1952 р. при кафедрі педагогіки був утворений педагогічний гурток, для роботи у якому записалися 22 студенти, відбулося чотири засідання на педагогічну тематику. І. П. Львов, як керівник гуртка, на одному із засідань прочитав доповідь "Сучасні завдання перебудови науки психології в світобаченні акад. І. П. Павлова" [1].

Іван Петрович показував для своїх колег приклад наукової діяльності, зокрема написав статті на тему: "Апперцепція і її значення в навчальному процесі", "Друга сигнальна система і взаємозв'язок іï̈ з першою". На жаль, 
вони не були опубліковані. Викладачі кафредри педагогіки відвідували семінари, на яких І. П. Львов виступав із доповідями [2].

Мудрий керівник кафедри цінував роботу кожного члена колективу, він високо оцінював роботу лаборанта кафедри Г. П. Свириди, вказуючи на її добросовісне виконання обов'язків: забезпечення студентів навчальною й рекомендованою літературою у вигляді окремих монографій, педагогічних журналів, газет, а також наочністю із психології, педагогіки та шкільної гігієни. Лаборант протягом року систематично поповнювала в кабінеті педагогіки та психології картковий тематичний каталог. Своєчасно кафедра організовувала педагогічні виставки, присвячені життєдіяльності А. С. Макаренка [2].

У Державному архіві Чернігівської області зберігається протокол № 2 засідання кафедри педагогіки і психології під керівництвом І. П. Львова, де рекомендовано викладачу психології І. П. Львову на практиці викладання психології більш детально розглядати вчення І. П. Павлова [4]. Викладачі кафедри дбали про престиж своєї педагогічної роботи, тому вносили корективи щодо поліпшення навчальної діяльності студентів. Члени кафедри в кінці кожного місяця на засіданні звітували про виконану роботу завідувачу кафредри І. П. Львову. Викладачі кафедри дослухалися до порад Івана Петровича, вони погодилися частіше відвідувати школи та долучатися до шкільного процесу в ході проходження педагогічної практики; щодо відставання педагогіки та психології від вимог того часу І. П. Львов рекомендував викладачам цих наук активно досліджувати життєво необхідні питання, проводити творчі дискусії з наукових проблем [4].

У 1953 р. вчена рада Чернігівського учительського інституту у зв'язку з негативними результатами зимової екзаменаційної сесії, ліберальним ставленням викладачів до студентів, халатним відношенням до читання лекцій, а також тим, що студентські організації не цікавилися навчанням відсталих студентів, направила такі вимоги до всіх кафедр інституту: кафедра повинна вникати в якість роботи своїх працівників; навчальна частина, дирекція інституту, завідувачі кафедрами повинні посилити контроль за якістю лекцій і практичних занять. Унаслідок цього завідувачі кафедрами мали надавати рецензії викладачам, розглядати особисто й писати свої зауваження на кожну стенограму лекції, на відкриту лекцію. Викладачі мали допомогти студентам, які відстали в навчанні, завідувачі кафедр і викладачі повинні організувати навчальну роботу студентів-заочників на високому рівні [4]. Аналіз протоколу вченої ради Чернігівського учительського інституту дає підстави стверджувати, що інститут забезпечував якісне навчання та підвищував контроль за читанням лекцій, використовуючи тогочасні новітні дидактичні матеріали, проведення семінарських занять, контролюючи якість знань.

У 1954-1955 н. р. І. П. Львов затвердив на засіданні кафедри робочий план занять із логіки зі студентами другого курсу словесно-літературного фракультету (українського й російського відділень). Отже, І. П. Львов працював не лише над новими методиками з педагогіки та психології, але й розробив методичні рекомендації з логіки. Учений запропонував вивчати гуманітаріям логіку в такій послідовності тем:

1. Поняття про мислення, знання про мислення і значення практики.

2. Предмет і значення логіки, різниця між психологічними й логічними предметами з погляду мислення, предмет формальної логіки, закони і форми мислення як відображення об'єктивної дійсності, формальна й діалектична логіка [4].
3. Логічні закони, поняття, визначення понять, поділ понять, види відношень між поняттями: поняття рівнозначні, перехресні, підпорядкування, протилежності, суперечності, судження, поділ суджень за змістом, поділ категоричних суджень за якістю [4].

Нами проаналізовано зміст документів адміністративної діяльності І. П. Львова й виявлено, що він зробив декілька зауважень у доповіді на засіданні кафедри педагогіки Чернігівського педагогічного інституту, також на засіданні Ради інституту із приводу питань, які були в доповіді "Про стан педагогічної науки та заходи ліквідації її відставання" на резолюцію І. А. Каїрова. У своїй доповіді він розкритикував резолюцію "Про стан педагогічної науки та заходи ліквідації її відставання" І. А. Каїрова та висловив сумнів про правильність підібраних заходів щодо наслідків відставання педагогічної освіти. І. П. Львов зауважив, що форми й методи навчання, вікові особливості та рівень підготовки студентів розглядаються окремо один від одного, тому він поставив під сумнів наукові рішення щодо впровадження загальних методів навчання у школах і закладах вищої освіти, що необхідно розробляти декілька рівнів для здобувачів освіти [6].

І. П. Львов зауважив, що в резолюції немає наукового аналізу негативних явищ у поведінці молоді, відсутня методика викладання цих явищ, не було наукового дослідження з питань співвідношення навчання й розумового розвитку студентів. На думку І. П. Львова, загальна педагогіка розроблена без записів ступенів розвитку й конкретних умов педагогічного процесу, а також існує недоопрацювання з боку автора резолюції, що пояснювалося слабким розвитком критики та самокритики [6].

У третьому пункті резолюції І. А. Каїрова І. П. Львов погодився з задачами, які поставила Академія педагогічних наук перед закладами освіти, Міністерством народної освіти, а саме: наукові працівники повинні всебічно творчо вивчати роботи класиків із педагогіки з питань виховання та шкіл, де головним завданням $€$ розв'язання педагогічних проблем.

Перспективи резолюції, на думку І. П. Львова, полягали у зверненні уваги на актуальні питання викладання педагогічних дисциплін, наукове розроблення теоретичних підручників із педагогіки, історії педагогіки та психології. І. П. Львов вважав, що потрібна підготовка монографій з основних галузей педагогіки, історії педагогіки, організації, проведення практичних і теоретичних занять, керівництва навчально-виховною роботою в закладах освіти. Академія повинна була допомогти українським сім'ям краще виховувати своїх дітей, надрукувати серію листівок, брошур з актуальних питань сімейного виховання та підготувати книгу "Практичний порадник для батьків". Педагогічна психологія повинна розроблятися не лише в системі психології, але й у системі педагогіки за актуальною тогочасною тематикою того [6].

У 1955 р. І. П. Львов був головою комісії з державних іспитів заочного відділення російської мови та літератури Чернігівського педагогічного інституту. У складі комісії були такі делегати: викладач російської літератури П. Г. Мінєєв, викладач російської мови Т. Д. Одинець, викладач педагогіки І. П. Куценко [7]. У звіті голови комісії про результати державної атестації зазначалося, що всі студенти-випускники виконали навчальний план, склали всі заліки й іспити, результати занесені в відповідну документацію, особові справи оформлені правильно, інститут створив усі умови для організації і проведення державних іспитів, які відбувалися у спокійних умовах. На думку науковця І. П. Львова, результати державних іспитів із педагогіки [7] показали, що студенти 
програмний матеріал засвоїли, більшість студентів відповідали правильно і стримано з питань дидактики, із питань теорії виховання, показали свої вміння застосовувати теоретичні знання в навчально-виховній роботі [7]. Аналіз відповідей студентів із педагогіки, за даними І. П. Львова, показав, що переважно були позитивні відповіді, але деякі студенти мали задовільні оцінки, матеріалом із педагогіки не добре володіли [7]. Більшість студентів, як вказано у звіті І. П. Львова, правильно відповідали про значення естетичного виховання (знання класичних опер, картин і їхніх авторів). На запитання
І. П. Львова про те, яким видом мистецтва студенти володіють, відповідь була негативна [7]. І. П. Львов запропонував розробити програму й дисципліну, щоб студенти вивчали мистецтво з погляду педагогіки.

І. П. Львов рекомендував викладачам кафедри педагогіки боротися проти вербалізмів у студентів, щоб студенти конспектували лекції, наводити приклади з педагогічної шкільної практики, рекомендувати студентам не обмежуватися підручником, читати педагогічні журнали, газети [7].

У таблиці № 1 показано успішність студентів-випускників, оцінки на державних іспитах [7].

Таблиця 1

Успішність студентів-випускників Чернігівського педінституту у 1954-55 н. р.

Фізико-математичне відділення

\begin{tabular}{|c|c|c|c|c|c|c|}
\hline Оцінка & 1 гр. & 2 гр. & 3 гр. & 4 гр. & В абсолютних цифрах & $\%$ \\
\hline Відмінно & 6 & 6 & 5 & 7 & 24 & 25 \\
\hline Добре & 7 & 6 & 11 & 6 & 30 & 31,25 \\
\hline Задовільно & 11 & 11 & 9 & 10 & 41 & 42,74 \\
\hline Незадовільно & - & 1 & - & - & 1 & 1 \\
\hline \multicolumn{7}{|c|}{ Відділення російської мови } \\
\hline Оцінка & 1 гр. & 2 гр. & 3 гр. & 4 гр. & В абсолютних цифрах & $\%$ \\
\hline Відмінно & 4 & 4 & 5 & 7 & 20 & 20 \\
\hline Добре & 10 & 5 & 7 & 7 & 29 & 29 \\
\hline Задовільно & 10 & 14 & 13 & 13 & 50 & 50 \\
\hline Незадовільно & 1 & - & - & - & 1 & 1 \\
\hline
\end{tabular}

Відділення української мови

\begin{tabular}{|l|c|c|c|c|c|c|}
\hline Оцінка & 1 гр. & 2 гр. & 3 гр. & 4 гр. & В абсолютних цифрах & $\%$ \\
\hline Відмінно & 4 & 3 & 4 & 1 & 12 & 11 \\
\hline Добре & 9 & 13 & 6 & 12 & 40 & 38,8 \\
\hline Задовільно & 14 & 10 & 14 & 13 & 51 & 49,5 \\
\hline Незадовільно & - & - & - & - & - & - \\
\hline
\end{tabular}

Представники кафедри педагогіки, яку очолював І. П. Львов, брали участь в обговоренні питань про політехнічну підготовку студентів фізико-математичного факультету інституту спільно з кафедрами фрізики й математики. І. П. Львов, як викладач психології, підготував доповідь із питання методики проведення групових консультацій із педагогічних дисциплін, на одному із засідань кафедри було обговорено статті "Глибоко розробляти проблеми соціалістичної педагогіки", "Творчий розвиток педагогічної науки" [2, арк. 16, 47].

У Чернігівському державному архіві зберігається заява як додаток до судового позову про академічну пенсію І. П. Львова, у якій вказано педагогічний стаж - 32 роки, 4 місяці і 28 днів. І. П. Львов працював у середній школі понад 18 років, у вищій школі при радянській владі працював 13 років і 7 місяців. І. П. Львов вважав за потрібне зазначити, що в Чернігівській духовній семінарії викладав світські, зокрема загальноосвітні (логіка, історія, фрілософрія) і педагогічні (психологія, дидактика), а не богословські дисципліни [9, арк. 4].

Висновки. Отже, аналіз роботи завідувача кафедри педагогіки І. П. Львова у 1952-1958 н. р. показав, що педагог відповідально ставився до своїх обов'язків: індивідуальні робочі плани членів кафедри вчасно затверджувалися, проводився контроль за лекціями й заняттями з педагогіки (правильно оформлена документація відповідного лекційного матеріалу), було розглянуто та затверджено робочий план педагогічної практики студентів, організовано контроль за самостійною роботою студентів першогого курсу з педагогіки, заслухано доповіді викладачів із педагогіки про навчальний процес студентів, здійснено підготовчу роботу кафедри щодо самостійного читання студентами рекомендованої літератури. Завдяки І. П. Львову на засіданнях кафедри керівники практики звітували перед кафедрою про педагогічну практику, про методику проведення заліків із педагогіки; слухали звіти викладачів із педагогіки щодо результатів їхньої роботи за другий семестр; проведено читання лекції методико-педагогічного характеру для батьків учнів; показано двосторонню діяльність між студентами й учнями під час педагогічної практики у школах м. Чернігова.

За керівництва І. П. Львова було підготовлено кафедру педагогіки до нового навчального року, здійснено перевірку готовності кафедри педагогіки до роботи зі студентами, збільшено аудиторний фронд, створено лабораторію для психологічних експериментів, придбано нову апаратуру для практичних занять із психології.

Список використаних джерел

1. Годовой отчет о работе кафедры педагогики Черниговского учительского института за 1951/52 учебный год, составленый Львовом И. П. (1952). - ДАЧО, ф.Р-1495, оп.1, спр. 15, арк. 1-26.

2. Годовой отчет о работе кафедры педагогики Черниговского учительского института за 1952/1953 учебный год, составленный Львовом И. П. (1953). - ДАЧО, ф. Р-1495, оп.1, спр. 16, арк. 1-69.

3. Информационная записка заведующего кафедрой педагогики Черниговского учительского института Львова И. П. о подготовке кафедры к новому учебному году в связи с замечаниями комиссии, обследованной работы кафедры (1950). - ДАЧО, ф. Р-1495, оп.1, спр. 14, арк. 1-8.

4. Письмо Министерства просвещения УССР о постановлении НК УССР и ЦККП(б)У от 12 февраля 1946 г. об установлении премии имени К. Д. Ушинского за научные труды по педагогике, постановление Совета Черниговского пединститута о результатах зимней экзаменационной сессии 1953 г., протокол заседания кафедры педагогики Черниговского учительского института и тезисы выступления на нем И. П. Львова (1951-1954). - ДАЧО, ф. Р-1495, оп.1, спр. 11, арк. 1-12.

5. План работы кафедры педагогики Черниговского учительского института на II семестр 1950-1951 учебного года и работы в базовой школе на I полугодие 1952-1953 учебного года (1950-1953). - ДАЧО, ф. Р1495, оп. 1 , спр. 12 , арк. 1-4.

6. О состоянии педагогической науки и мерах ликвидации ее отставания - резолюция по докладу президента Академии педагогических наук РСФСР И. А. Каирова на совещании по вопросам педагогики и план мероприятий АПН в связи с задачами, выдвинутыми совещанием; доклад заведующего кафедрой педагогики Черниговского пединститута доцента Львова И. П. на заседании Совета института по обсуждению этих документов (1955). - ДАЧО, ф. Р-1495, оп.1, спр. 10, арк. 1-32. 
7. Отчет о проведении государственных выпускных экзаменов по заочному отделению русского языка и литературы Черниговского учительского института (1955). - ДАЧО, ф. Р-1495, оп.1, спр. 17, арк. 1-20.

References

1. Godovoj otchet o rabote kafedry pedagogiki CHernigovskogo uchitel'skogo instituta za 1951/52 uchebnyj god, sostavlenyj Lvovom I. P. (1952). DACHO, f.R-1495, op.1, spr. 15, 26 .

2. Godovoj otchet o rabote kafedry pedagogiki CHernigovskogo uchitelskogo instituta za 1952/1953 uchebnyj god, sostavlennyj Lvovom I. P. (1953). - DACHO, f. R-1495, op.1, spr. 16, 69.

3. Informacionnaya zapiska zaveduyushchego kafedroj pedagogiki CHernigovskogo uchitel'skogo instituta Lvova I. P. o podgotovke kafedry $k$ novomu uchebnomu godu v svyazi s zamechaniyami komissii, obsledovannoj raboty kafedry (1950). - DACHO, f. R-1495, op.1, spr. 14, 8.

4. Pismo Ministerstva prosveshcheniya USSR o postanovlenii NK USSR $\mathrm{CKKP}(\mathrm{b}) \mathrm{U}$ ot 12 fevralya $1946 \mathrm{~g}$. ob ustanovlenii premii imeni K. D. Ushinskogo za nauchnye trudy po pedagogike, postanovlenie Soveta CHernigovskogo pedinstituta o rezul'tatah zimnej ekzamenacionnoj sessii
1953 g., protokol zasedaniya kafedry pedagogiki CHernigovskogo uchitel'skogo instituta i tezisy vystupleniya na nem I. P. Lvova (1951-1954). DACHO, f. R-1495, op.1, spr. 11, 12

5. Plan raboty kafedry pedagogiki CHernigovskogo uchitelskogo instituta na II semestr 1950-1951 uchebnogo goda i raboty $v$ bazovoj shkole na I polugodie 1952-1953 uchebnogo goda (1950-1953). - DACHO, f. R-1495, op. 1 , spr. 12,4

6. O sostoyanii pedagogicheskoj nauki i merah likvidacii ee otstavaniya rezolyuciya po dokladu prezidenta Akademii pedagogicheskih nauk RSFSR I. A. Kairova na soveshchanii po voprosam pedagogiki i plan meropriyatij APN v svyazi s zadachami, vydvinutymi soveshchaniem; doklad zaveduyushchego kafedroj pedagogiki CHernigovskogo pedinstituta docenta Lvova I. P. na zasedanii Soveta instituta po obsuzhdeniyu etih dokumentov (1955). - DACHO, f. R-1495, op.1, spr. 10, 32.

7. Otchet o provedenii gosudarstvennyh vypusknyh ekzamenov po zaochnomu otdeleniyu russkogo yazyka i literatury CHernigovskogo uchitelskogo instituta (1955). - DACHO, f. R-1495, op.1, spr. 17, 20.

Надійшла до редколегії 07.12.19

A. Ostapenko, postgraduate student

Taras Shevchenko National University of Kyiv, Kyiv, Ukraine

\section{MANAGEMENT ACTIVITY OF IP LVOV IN THE POSITION OF HEAD OF THE DEPARTMENT OF PEDAGOGY OF THE CHERNIGIV PEDAGOGICAL INSTITUTE (1952-1958)}

The article shows I. P. Lvov, chairman of the Department for pedagogy of Chernihiv Pedagogical Institute.

I. P. Lvov worked as the Head of the Department of Pedagogy from 1952 to 1958 . He developed didactic materials on pedagogy, logic and psychology. The curriculum for the second semester was analyzed, where the main tasks were students' educational work, advanced training of teachers and realization of public works under the teachers.

At the faculty meeting, the lecturers approved the Individual work plans of the members of the department, monitoring the lectures and pedagogical lessons from the point of view of scientific and methodological execution, control over the work of a laboratory assistant, review and approval of the work plan of pedagogical practice of students.

I. P. Lviv had intended to purchase a separate room for conducting psychological experiments. Unfortunately, the intention failed for unknown reasons. He controlled the quality of lectures and seminars on pedagogy, lectures on psychology, and reported on the visit by the directorate of the institute and individual members of the chair they reviewed.

In 1952, a pedagogical circle was formed at the department of pedagogy. I. P. Lviv was group leader of the circle at one of the meetings read a report "Modern problems of restructuring the science of psychology in the academician I. P. Pavlov".

I. P. Lviv appreciated the work of the laboratory assistant of the department of G. P. Svirid, pointing to her faithful discharge of her duties: providing students with educational and recommended literature.

The content of the documents of I. P. Lvov on an administrative post was analyzed and he was found that he made some comments in the report at the meeting of the pedagogy department of the Chernihiv Pedagogical Institute, as well as at the meeting of the Institute council concerning the issues that were in the report "On the condition of pedagogical science and eliminating its backlog" on the resolution of I. A. Kairov.

In $1955 \mathrm{I}$. P. Lvov was the head of the commission on State examinations of the correspondence department of the Russian language and literature of the Chernihiv Pedagogical Institute. Analysis of students' answers in pedagogy, according to I. P. Lvov, showed that most were positive answers, but some students had satisfactory grades, they did not possess good material in pedagogy.

Keywords: resolution, lecturer, Head of the Department of Pedagogy, I. P. Lviv.

удК 316.37.013.78

DOI: https://doi.org/10.17721/2415-3699.2020.12.10

О. Поляк, канд. пед. наук, доц. Київський національний університет імені Тараса Шевченка, Київ

\section{РОзвИТОК СОЦІОЛОГІЧнОї ОСвІтИ В УКРАїнІ}

Досліджено становлення соціології як науки та навчальної дисципліни, доведено явище значного впливу індивідуальних рис і знань творців соціології на їі розвиток на початковій стадії, досліджено причини відмін в еволюції соціології в Західній Європі, США, $і$ Східній Європі. Запропоновані вдосконалення цього періоду в підручниках для ЗВО.

Виявлено помилковість поширеного в сучасних підручниках твердження про відсутність соціологічних досліджень у радянському Союзі. Вказано на факти їхнього розвитку у 20-30-х рр. у формі пошуку "наукові організації праці" та у 60-70-х рр. у формі здійснення "соціальних передбачень".

Вивчено відновлення соціології і формування соціологічної освіти в незалежній Україні. Досліджено навчальні плани й інші аспекти підготовки фахівців соціологічних профілів у ЗВО, вказано на існування неузгодженості термінології формулювань у дипломах зВО з офіційним Класифікатором професій.

Ключові слова: сочіологічна думка, сочіологія, сочіологічна освіта.

Постановка проблеми. Аналіз наукових праць із педагогіки та соціології засвідчив, що термін "соціологічна освіта в Україні" в них не зустрічався жодного разу. Зокрема не здійснювалось системне дослідження педагогічних і загальнонаукових проблем розвитку сектору соціологічної освіти.

Натепер прискорився процес модернізації закладів вищої освіти та іїі інтеграції до європейського освітнього простору. Передбачено виконання комплексу завдань щодо реформування системи вищої освіти в Україні, зокрема:
- модернізації системи вищої освіти, системи і структури кваліфрікацій

- удосконалення змісту вищої освіти та організації навчального процесу.

Реалізація цих завдань у системі закладів вищої освіти (ЗВО) України сприятиме досягненню основної мети - підготовки висококваліфікованих фахівців, які будуть конкурентоспроможними на національному, європейському та світовому ринках праці. 